\title{
AVALIAÇÃO DA CONDIÇÃO DE BALNEABILIDADE DAS PRAIAS DE NATAL/RN NO PERÍODO DE 2004-2009
}

\author{
C. E. A. Valadão' e A. L. C. Araújo² \\ ${ }^{1}$ Especialista em Gestão Ambiental \\ ${ }^{2}$ Professor do Instituto Federal de Educação, Ciência e Tecnologia do Rio Grande do Norte \\ andre.calado@ifrn.edu.br
}

Artigo submetido em julho/2012 e aceito em agosto/2012

\section{RESUMO}

As condições de balneabilidade foram investigadas a partir dos limites de coliformes fecais encontrados em amostras coletadas em sete estações de monitoramento, ao longo do período de 2004-2009, no município de Natal-RN. Análises da evolução temporal das condições de balneabilidade, bem como dos percentuais anuais obtidos para as situações em que a praia foi classificada como PRÓPRIA para banho, foram realizadas segundo critérios estabelecidos pela resolução CONAMA no 274/00. Os resultados indicaram que, com exceção da praia da Via Costeira/Mãe Luiza (NA07), as demais praias de Natal possuem boa qualidade ambiental. As praias Barreira d'Água (NA06) e Cacimba do Boi (NA05), ambas localizadas na Via
Costeira, destacaram-se por apresentar as melhores condições de balneabilidade. Seus percentuais anuais de condições PRÓPRIAS para banho foram superiores a $98 \%$ e $92 \%$, respectivamente, para todos os anos analisados. Por outro lado, a praia da Mãe Luiza (NA07) continuamente apresentou números máximos prováveis de coliformes fecais extremamente elevados, caracterizando uma situação de constante contaminação e degradação ambiental. Embora a precipitação seja um dos fatores que pode influenciar a qualidade ambiental de uma praia, não foi possível estabelecer uma relação direta entre precipitação semanal e quantidade de coliformes fecais para as estações analisadas.

PALAVRAS-CHAVE: Coliformes totais. Precipitação. Praias urbanas. Qualidade ambiental. Natal/RN.

\section{EVALUATION OF BATH CONDITION ON SEVEN BEACHES OF NATAL-RN OVER THE PERIOD OF 2004 TO 2009}

\section{ABSTRACT}

The balneability conditions were investigated through samples collected in seven monitoring points along the Natal-RN coast during the period of 2004-2009. Temporal evolution of balneability conditions and annual percentage of proper bathing conditions were analyzed according to the Brazilian standards established by the CONAMA 274/00 resolution. Results showed that all but the Via Costeira/Mãe Luiza beach presented good environmental quality. The beaches of Barreira d'Água and Cacimba do Boi, both located at Via Costeira, presented the best environmental quality, showing each year proper bathing conditions over $98 \%$ and 92\%, respectively. In contrast, Mãe Luiza beach repeatedly presented extremely high MPN of faecal coliforms, which means it presented a poor balneability condition for most of the period under analysis. Precipitation may be considered one the factors influencing balneability conditions, however we could not establish a clear relationship between the accumulated amount of weekly precipitation and the MPN of faecal coliforms for the sampling points considered.

KEY-WORDS: Fecal Coliforms. Precipitation. Urban beaches. Environmental quality. Natal/RN 


\section{AVALIAÇÃO DA CONDIÇÃO DE BALNEABILIDADE DAS PRAIAS DE NATAL/RN NO PERÍODO DE 2004-2009}

\section{INTRODUÇÃO}

De acordo com Sachs (2008) estamos vivendo a terceira grande transição, da era petrolífera para a biocivilização do futuro. Para ele, a primeira transição foi marcada pela passagem do homem da simples coleta e da caça para a agricultura e criação de animais, ocorrida há milhares de anos atrás. A segunda é representada pela era dos abundantes e baratos combustíveis fósseis (carvão, petróleo e gás), iniciada há poucos séculos. Agora, portanto, segundo ele, estaríamos vivendo no umbral da terceira grande transição, onde a era do petróleo seria deixada para trás e estaríamos caminhando rumo à emergência das biocivilizações. Nas palavras de Sachs "esta transição levará décadas, mas, segundo muitos indícios, já começou, empurrada pela alta espetacular dos preços do petróleo e pela recuperação dos preços dos alimentos".

Já a longa história da co-evolução da espécie humana com a biosfera levou-nos à constatação de que os modelos até então adotados não mais são possíveis. A degradação ambiental e o uso irracional dos recursos naturais que ocorreram ao longo do nosso processo evolutivo provocaram e têm provocado transformações significativas por todo o planeta. Estas transformações alcançaram uma dimensão tal que passaram a ameaçar a capacidade de manutenção e sustentação da vida no planeta, e trouxeram consigo reflexos profundos na qualidade de vida e na qualidade ambiental.

As discussões atuais giram em torno dos processos econômicos, e de questões relacionadas a como continuar a ser produtivo, que preço deve ser pago para a recuperação e preservação/conservação do meio ambiente, como garantir o desenvolvimento de modo a satisfazer as necessidades do presente sem comprometer a capacidade das gerações futuras satisfazerem suas próprias necessidades. Ou, em outras palavras, como continuar o desenvolvimento de forma que este seja sustentável. Discute-se que é preciso haver a internalização dos custos ambientais do processo produtivo, para que cada atividade tenha seus impactos devidamente contabilizados e isto seria representado por processo que dependeria, basicamente, da identificação de impactos ambientais e de sua correta valoração econômica. Todavia, uma nova discussão surge relacionada à questão de como fazer a valoração econômica do meio ambiente (SEILERT, 2009; PORTILHO, 2005; MATTOS, 2000; PORTILHO, 2009, para citar apenas alguns).

Para Sachs (1993) todo o planejamento de desenvolvimento precisa levar em conta, simultaneamente, cinco dimensões da sustentabilidade: sustentabilidade social, econômica, ecológica, espacial e cultural. A primeira dimensão refere-se à equidade social, cuja meta seria construir uma civilização com maior equidade na distribuição de renda e de bens, de modo a permitir haver uma redução do abismo existente entre os padrões de vida dos ricos e dos pobres. A sustentabilidade econômica refere-se não só à necessidade de manter fluxos regulares de investimentos, uma preocupação dominante nos planos de desenvolvimento tradicionais, mas também à gestão eficiente dos recursos produtivos. Além disso, é necessário que os benefícios do crescimento econômico fiquem na região ou local para fortalecer as fontes endógenas de poupança e investimento (BARBIERI, 2000). Já a sustentabilidade ecológica refere-se às ações 
para ampliar a capacidade de carga do planeta, evitando danos aos sistemas de sustentação da vida; à limitação do consumo de combustíveis fósseis e de outros recursos e produtos facilmente esgotáveis, substituindo-os por recursos ou produtos renováveis e/ou abundantes; à redução das emissões de poluentes, preservação da biodiversidade, etc. A sustentabilidade espacial, por sua vez, diz respeito à busca de uma configuração rural-urbana equilibrada e uma melhor solução para os assentamentos humanos e das atividades econômicas. E, por fim, a sustentabilidade cultural concerne ao respeito que deve ser dado às diferentes culturas e às suas contribuições para a construção de modelos de desenvolvimento apropriados às especificidades de cada ecossistema, cada cultura e cada local (BARBIERI, 2000).

No discurso ecológico original, que teve sua origem com os movimentos de contestação do estilo de vida industrial e urbano, é feita a identificação da ideologia do consumismo (base do modelo capitalista) como um dos pilares da atual crise ambiental. A partir dele surge a percepção da insustentabilidade dos padrões de produção e consumo, revelando a preocupação com a escassez e o esgotamento dos recursos naturais e com a extinção de determinadas espécies representantes da vida selvagem. Segundo Portilho (2009), esta percepção inaugurou uma nova fase no movimento ambientalista, criando uma mudança de rumo que aponta para a consideração do longo prazo e dos direitos das gerações futuras, contrariando o imediatismo ditado pelo sistema de produção. Por outro lado, passa a acontecer uma apropriação de parte do ideário ecológico pelo setor empresarial, onde este passa a se auto-intitular como o principal segmento capaz de levar adiante o projeto de uma sociedade ambientalmente sustentável. Portilho (2009) ressalta:

Assim, enquanto os paradigmas vigentes nas sociedades industrializadas de consumo são apontados, pelos grupos ambientalistas originais, como a causa primeira da problemática ambiental, o setor empresarial postula exatamente o contrário, ou seja, que o mercado e o capital serão capazes de resolver todos os constrangimentos ambientais, dentro do atual e hegemônico modelo de desenvolvimento econômico, sobretudo através da competitividade empresarial que estimularia o uso de tecnologias limpas, o desenvolvimento de produtos "verdes" e "ecologicamente corretos" e a visão de meio ambiente como nova possibilidade de negócio. A conscientização ecológica e a conseqüente pressão exercida pelos consumidores que buscam produtos "verdes" também são apontadas como exemplos de auto-regulação do mercado, assumindo, quase que "naturalmente", os constrangimentos ambientais. Paradoxalmente, se para alguns a civilização industrial tecnológica de consumo é apontada como determinante da crise ambiental, para outros, esta é justamente a solução.

As discussões sobre questões ambientais são amplas e os problemas que se colocam são muitos e perpassam todas as áreas do saber humano. Porém, concordando com Portilho (2009), uma questão central a ser destacada é a possibilidade ou não de exercício da cidadania através do consumo. Ela nos pergunta:

Estamos, ao consumir, constituindo uma nova maneira de ser cidadãos ou, ao contrário, o consumo substitui e impede o desenvolvimento de uma cidadania plena? Compreender melhor os vínculos entre consumo e 
cidadania pode ser um bom começo. Ficam esboçadas, ainda, duas últimas questões: qual o conceito de cidadania pretendida pelo movimento ambientalista original e pode esta ser alcançada através da ética individual do consumo, seja ele "verde" ou não?

A partir destas reflexões, podemos suspeitar que tanto o estímulo ao "consumo verde" (como o lugar de exercício da cidadania e pressão por mudanças tecnológicas), quanto as suas críticas, responsabilizam exclusivamente o consumidor, enquanto atenuam a responsabilização do sistema de produção e reforçam a ética individual em detrimento da ética coletiva.

Em geral, a relação Homem vs. Natureza resulta num processo não harmonioso, onde os recursos ambientais são normalmente utilizados além da capacidade de suporte do sistema. Para Clark (1996), a capacidade de suporte está relacionada com o nível máximo de atividade a partir do qual ocorrerá a deterioração física do recurso ou dano ao ambiente natural. A Política Nacional de Meio Ambiente (PNMA), instituída pela Lei no 6.938/81, estabelece uma série de instrumentos de gestão ambiental, entre eles o estabelecimento de padrões de qualidade ambiental e garantia da prestação de informações relativas ao meio ambiente, obrigando o poder público a produzi-las quando inexistentes.

O estado do Rio Grande do Norte (RN) tem recebido um grande número de turistas atraídos pela beleza natural de suas praias, sendo que o principal aporte turístico se dá em Natal. Além disso, Natal tem sofrido uma grande expansão urbana ao longo das duas últimas décadas. Com um contingente populacional e um fluxo turístico cada vez maiores, a demanda por serviços de infra-estrutura urbana ressalta uma série de deficiências quanto ao saneamento, moradias, abastecimento d'água e de energia elétrica, segurança, degradação ambiental e legalização das áreas ocupadas na cidade.

A avaliação da qualidade das águas destinadas à recreação de contato primário (balneabilidade) se enquadra na gestão ambiental na medida em que é entendida como verificação de critério de uso, instrumento de controle de qualidade e insumo para a formulação de políticas de desenvolvimento. Por recreação de contato primário entende-se aquele contato direto e prolongado com a água (natação, mergulho, esqui-aquático, etc.), onde a possibilidade de ingerir quantidades significativas de água é também expressiva (IDEMA, 2005, 2008). O RN vem desenvolvendo ao longo dos últimos anos um monitoramento sistemático das condições de balneabilidade de suas praias através do projeto "Estudo de Balneabilidade das Praias do Estado do Rio Grande do Norte" (IFRN, 2010). Este se encontra inserido no programa estadual "Água Azul", o qual é executado conjuntamente pelo Instituto de Desenvolvimento Econômico e Meio Ambiente do Rio Grande do Norte (IDEMA), pela Fundação de Apoio à Educação e ao Desenvolvimento Tecnológico do Rio Grande do Norte (FUNCERN) e pelo Instituto Federal de Educação, Ciência e Tecnologia do Rio Grande do Norte (IFRN). O estudo das condições de balneabilidade das praias potiguares é feito com base nos critérios estabelecidos em conformidade com as especificações das resoluções no 020/86 e no 274/00 do Conselho Nacional de Meio Ambiente (CONAMA) (CONAMA, 1986, 2000). 
Neste contexto, o presente trabalho busca contribuir com o planejamento urbano do município de Natal/RN no contexto de uma sociedade ambientalmente sustentável, através da análise da evolução das condições de balneabilidade de suas praias.

\section{MATERIAL E MÉTODOS}

As águas doces, salobras e salinas, destinadas à recreação de contato primário, podem ser classificadas de acordo com a resolução CONAMA no 274/00, nas categorias IMPRÓPRIA e PRÓPRIA, podendo ser utilizado como critério de enquadramento a quantidade de coliformes fecais encontrada em um conjunto de cinco amostras, coletadas durante semanas consecutivas. A categoria PRÓPRIA pode ainda se subdividir nas categorias EXCELENTE, MUITO BOA, SATISFATÓRIA ou IMPRÓPRIA, conforme a Tabela 1.

Tabela 1 - Enquadramento das condições de balneabilidade segundo a resolução CONAMA no 274/00.

\begin{tabular}{c|c|l}
\hline CATEGORIA SIMPLIFICADA & CATEGORIA & LIMITE DE COLIFORMES FECAIS ( $\left.{ }^{*} \mathrm{NMP} / 100 \mathrm{ml}\right)$ \\
\hline \multirow{2}{*}{ PRÓPRIA } & EXCELENTE & Máximo de 250 em $80 \%$ ou mais das amostras \\
\cline { 2 - 3 } & MUITO BOA & Máximo de 500 em $80 \%$ ou mais das amostras \\
\cline { 2 - 3 } & SATISFATÓRIA & Máximo de 1000 em $80 \%$ ou mais das amostras \\
\hline IMPRÓPRIA & IMPRÓPRIA & Acima de 1000 em mais de $20 \%$ das amostras \\
\hline
\end{tabular}

* Número mais provável (NMP).

O programa Água Azul realiza levantamentos sistemáticos das condições de balneabilidade em várias estações de monitoramento, distribuídas ao longo da costa potiguar, sendo quinze delas localizadas em Natal (Figura 1). Os dados utilizados neste estudo foram fornecidos pelo programa e correspondem às quantidades de coliformes fecais obtidas através das amostras coletadas em sete estações localizadas em Natal, ao longo de cinquenta e duas semanas, durante o período de 2004 a 2009. Embora o monitoramento realizado seja contínuo, no ano de 2007 a coleta foi feita em 47 semanas, em 2008 em 51 semanas e 2009 em 50 semanas. Na tabela 2 pode ser visto os locais de coleta e suas respectivas coordenadas sendo suas localizações ilustradas na Figura 1. Também foram utilizados dados de precipitação diária de Natal para o mesmo período, fornecidos pela Empresa de Pesquisa Agropecuária do Rio Grande do Norte (EMPARN), visando avaliar a influência das chuvas nas condições de balneabilidade.

Tabela 2 - Relação das praias monitoradas e localização precisa dos pontos de coleta de amostras. Fonte: adaptado de IDEMA (2005).

ESTAÇÃO DE MONITORAMENTO PRAIA/LOCAL DA COLETA COORDENADAS UTM

\begin{tabular}{llcc} 
& & ESTE & NORTE \\
\hline NA01 & Ponta Negra/Morro do Careca & 260046 & 9349179 \\
NA02 & Ponta Negra/Acesso Principal & 259680 & 9349347 \\
NA03 & Ponta Negra/Free Willy & 259152 & 9349887 \\
NA04 & Ponta Negra/Final do Calçadão & 258698 & 9350841 \\
\hline
\end{tabular}




\begin{tabular}{llll}
\hline NA05 & Via Costeira/Cacimba do Boi & 258612 & 9351454 \\
NA06 & Via Costeira/Barreira d'Água & 258376 & 9354778 \\
NA07 & Via Costeira/Mãe Luíza & 258458 & 9358850 \\
\hline
\end{tabular}

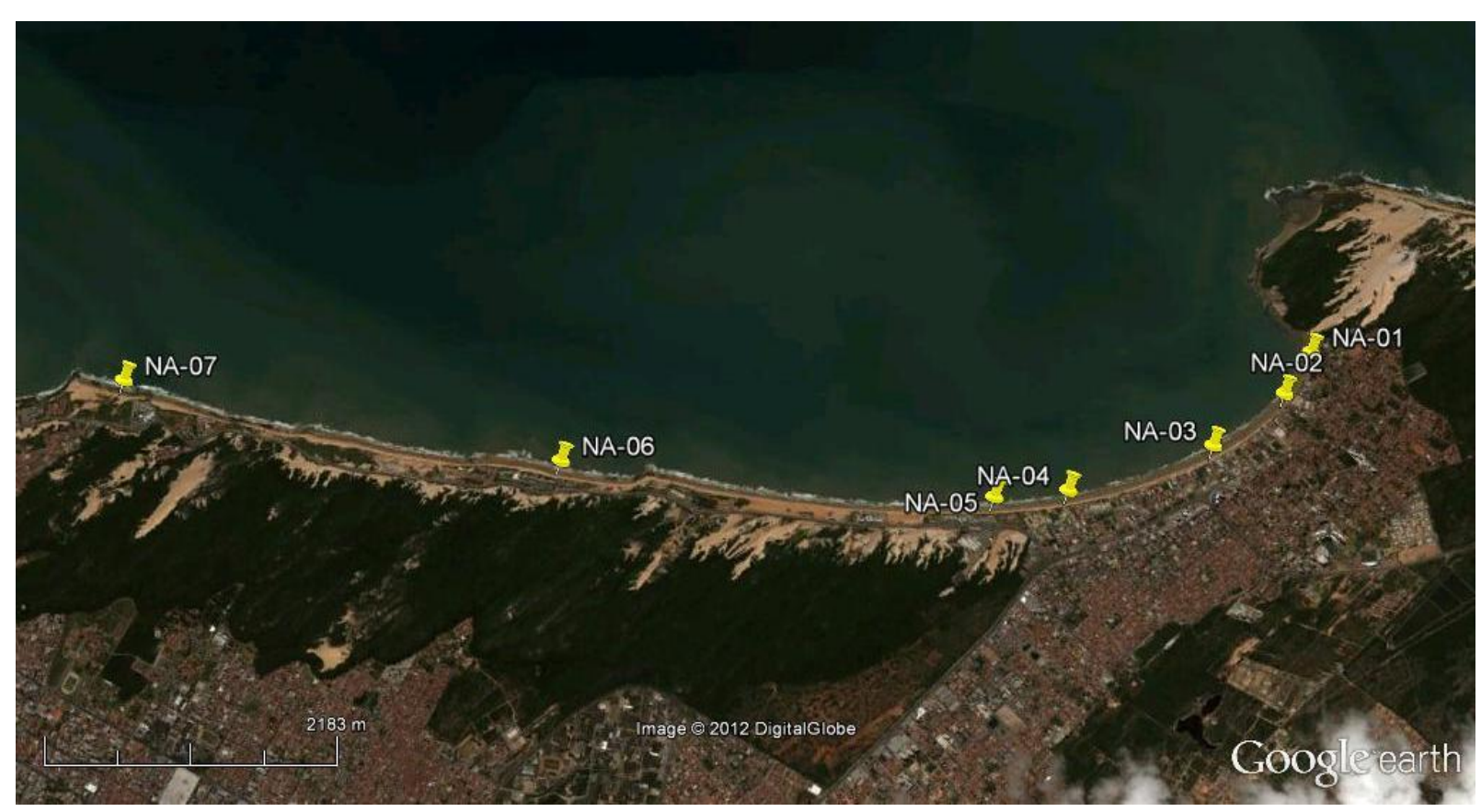

Figura 1 - Localização das estações monitoradas na Região Metropolitana de Natal/RN. Fonte: Google earth, 17/07/2012 (imagem de 08/2011).

O estudo consistiu da análise da evolução temporal das condições de balneabilidade com base no número mais provável (NMP) de microorganismos do tipo bactérias coliformes fecais encontrado em $100 \mathrm{~mL}$ de amostra de água para cada estação de monitoramento de Natal. Para tanto foi investigada a distribuição da quantidade de coliformes fecais ao longo de toda a série e dos percentuais anuais obtidos para as situações em que a praia foi classificada como PRÓPRIA para banho. Também foram realizadas análises da distribuição da precipitação para os períodos em que foram encontrados os maiores valores de coliformes fecais, considerando-se a precipitação acumulada na semana correspondente à coleta de cada uma das amostras.

\section{RESULTADOS E DISCUSSÕES}

A análise das Figuras de 2 a 8 evidencia comportamentos bastante distintos entre as estações monitoradas. Nota-se que em algumas semanas as estações NA01 e NA03, localizadas em Ponta Negra, chegaram a apresentar limites máximos da ordem de $9.000 \mathrm{NMP} / 100 \mathrm{~mL}$. A estação NAO2 teve valores máximos em torno de $5.000 \mathrm{~mL}$, ao passo que a NA04 teve um episódio da ordem de $30.000 \mathrm{NMP} / 100 \mathrm{~mL}$ na semana 74 (correspondendo à semana 22/2005, mês de junho). Porém, na maioria das semanas os limites encontrados foram inferiores a 1.000 $\mathrm{mL} / 100 \mathrm{~mL}$. Os valores de coliformes fecais encontrados nas estações NA05 e NA06 da praia da Via Costeira apresentam um limite máximo de $3.000 \mathrm{NMP} / 100 \mathrm{~mL}$ ao longo de toda a série de dados. Já a estação NA07, localizada na praia Via Costeira/Mãe Luiza, se caracteriza por 
apresentar limites extremamente altos na maior parte da série. Destaca-se ainda que em várias semanas os limites encontrados são de centenas de milhares de coliformes fecais, cujo pico ocorreu na semana 170 (correspondendo à semana 14/2005, mês de abril) no valor de 900.000 $\mathrm{NMP} / 100 \mathrm{~mL}$, conforme ilustrado na Figura $8 \mathrm{~b}$. Estes altos valores de coliformes fecais encontrados na estação NA07 mostram que a situação de contaminação em que se encontra a praia Via Costeira/Mãe Luiza exige que medidas mitigadoras e ações que visem a redução e/ou eliminação dos agentes causadores das contaminações sejam tomadas pela prefeitura e órgãos de fiscalização ambiental.

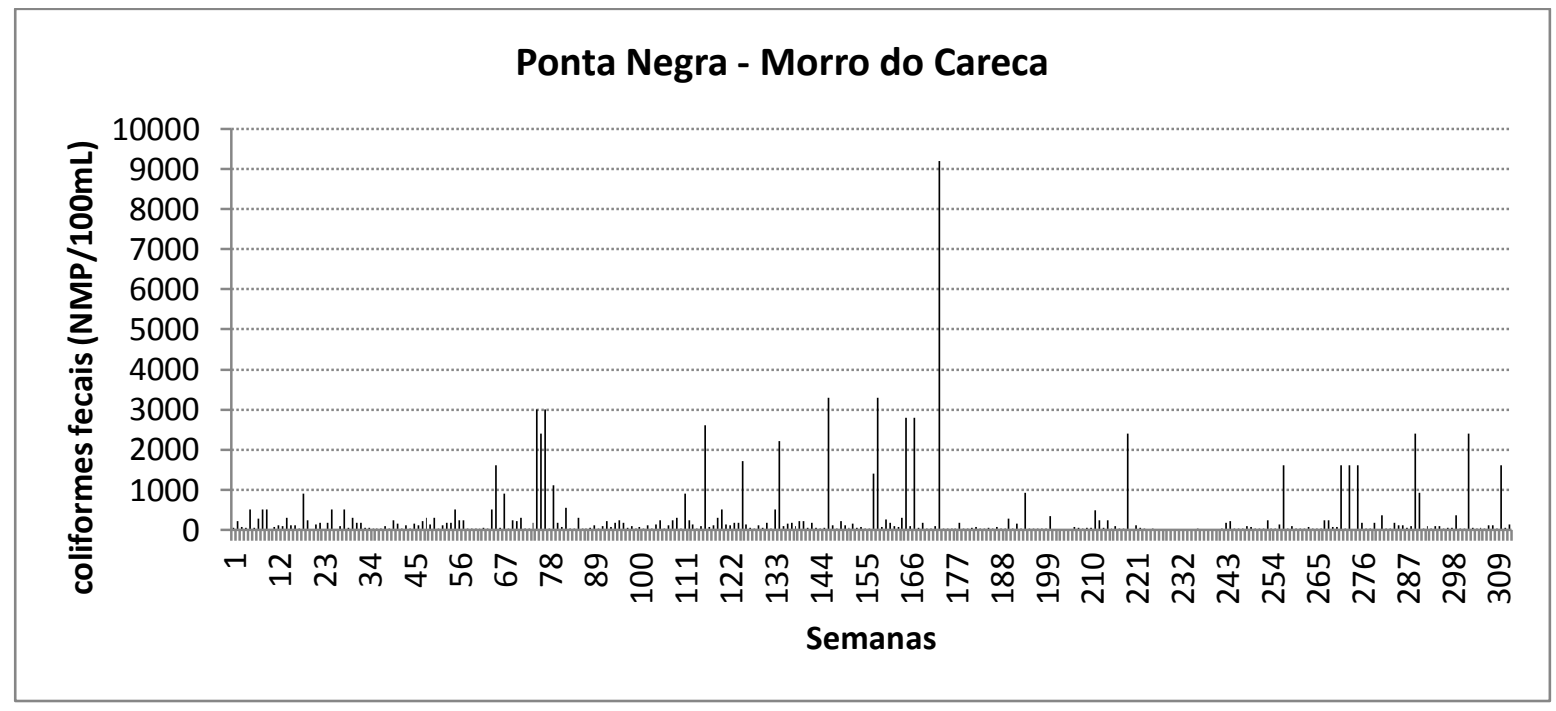

Figura 2 - Evolução temporal da quantidade de coliformes fecais encontrada na estação de monitoramento NA-01, no período de 2004 a 2009. Fonte: Dados da pesquisa.

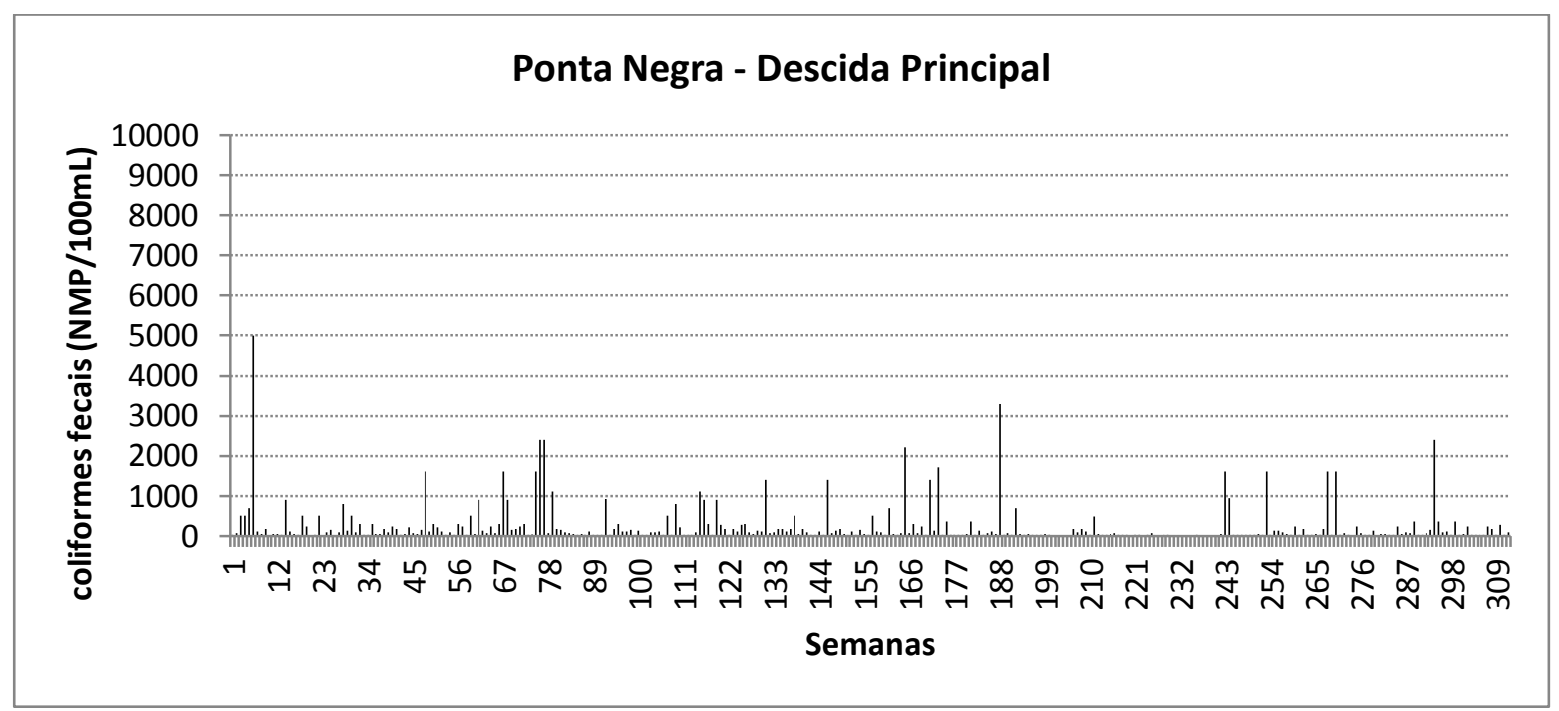

Figura 3 - Evolução temporal da quantidade de coliformes fecais encontrada na estação de monitoramento NA-02, no período de 2004 a 2009. Fonte: Dados da pesquisa. 


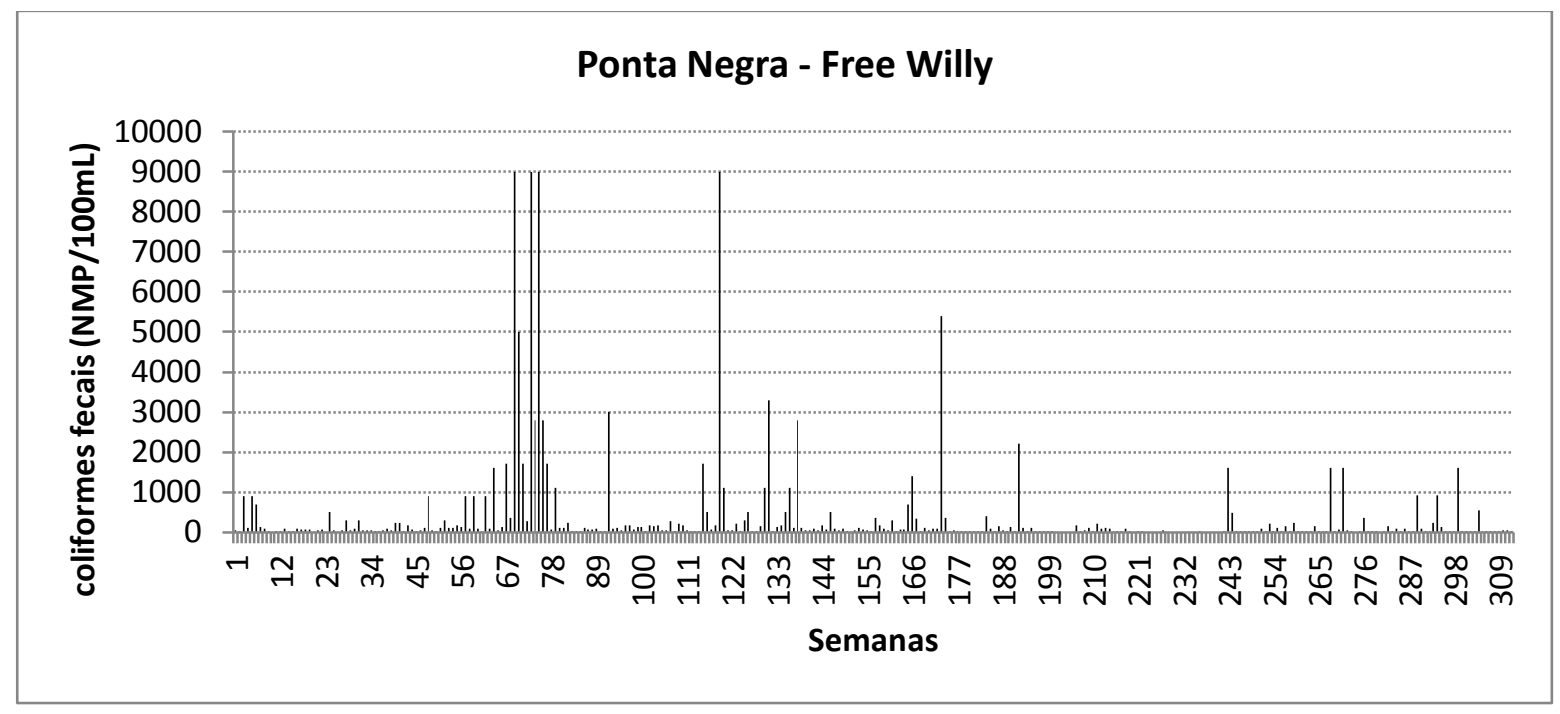

Figura 4 - Evolução temporal da quantidade de coliformes fecais encontrada na estação de monitoramento NA-03, no período de 2004 a 2009. Fonte: Dados da pesquisa.

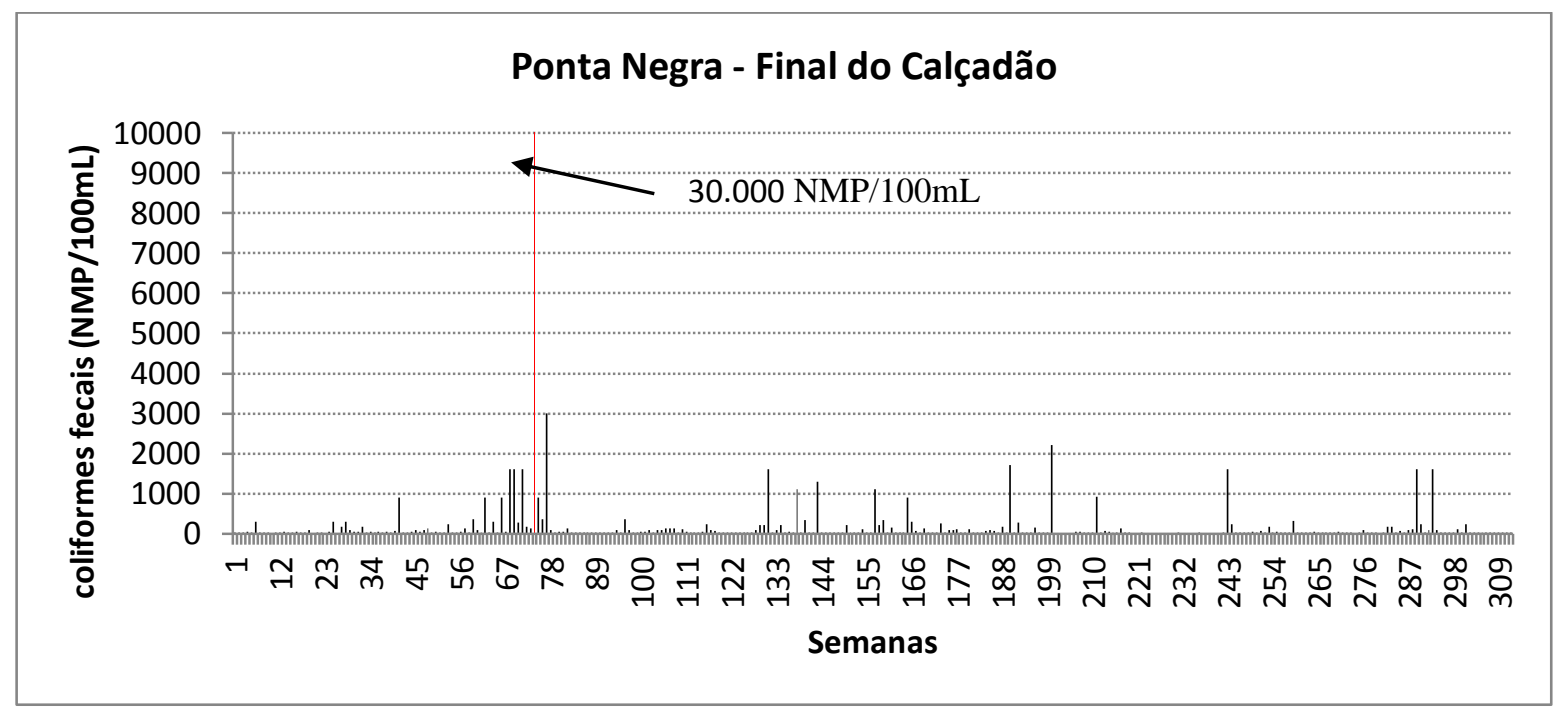

Figura 5 - Evolução temporal da quantidade de coliformes fecais encontrada na estação de monitoramento NA-04, no período de 2004 a 2009. Destaque em vermelho ao maior valor alcançado, ocorrido na semana 74 (junho/2005). Fonte: Dados da pesquisa. 


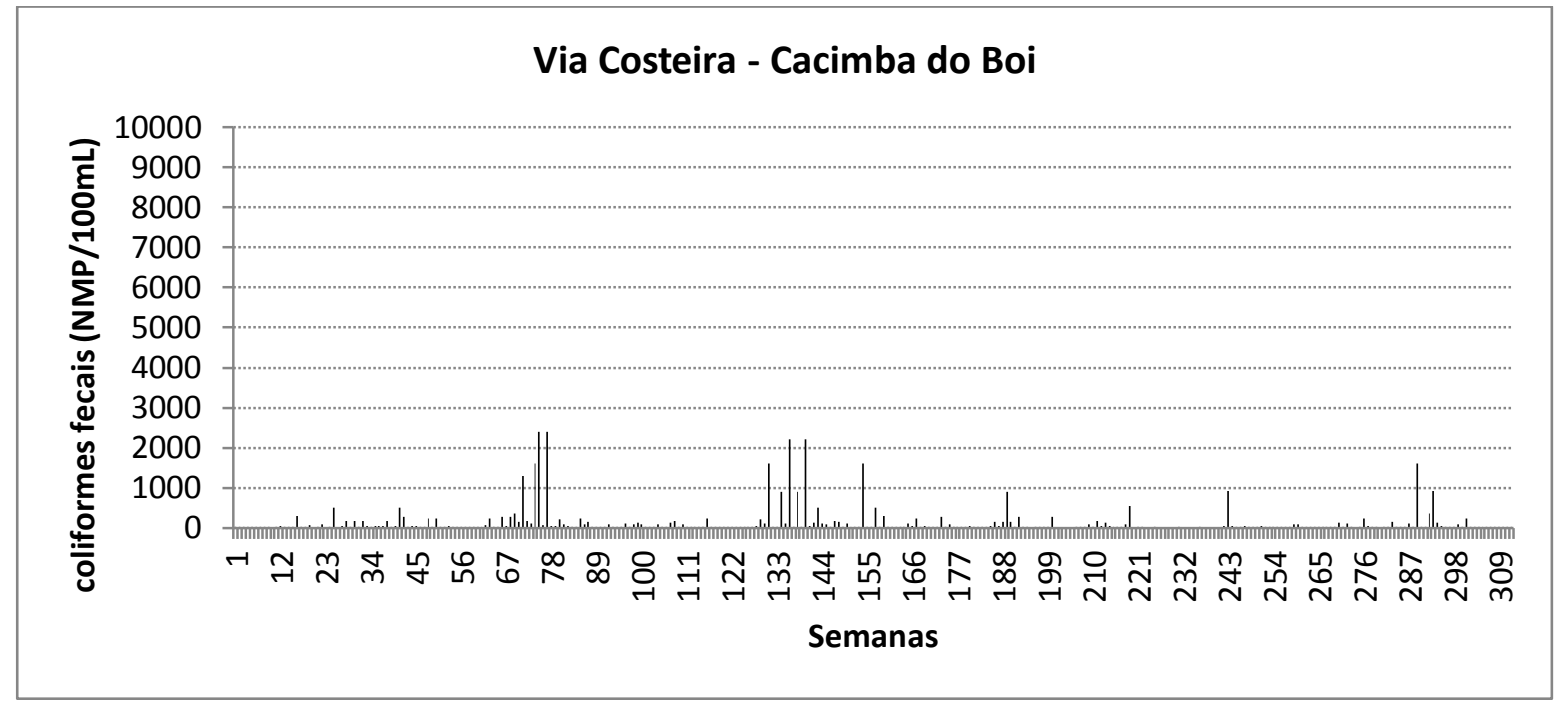

Figura 6 - Evolução temporal da quantidade de coliformes fecais encontrada na estação de monitoramento NA-05, no período de 2004 a 2009. Fonte: Dados da pesquisa.

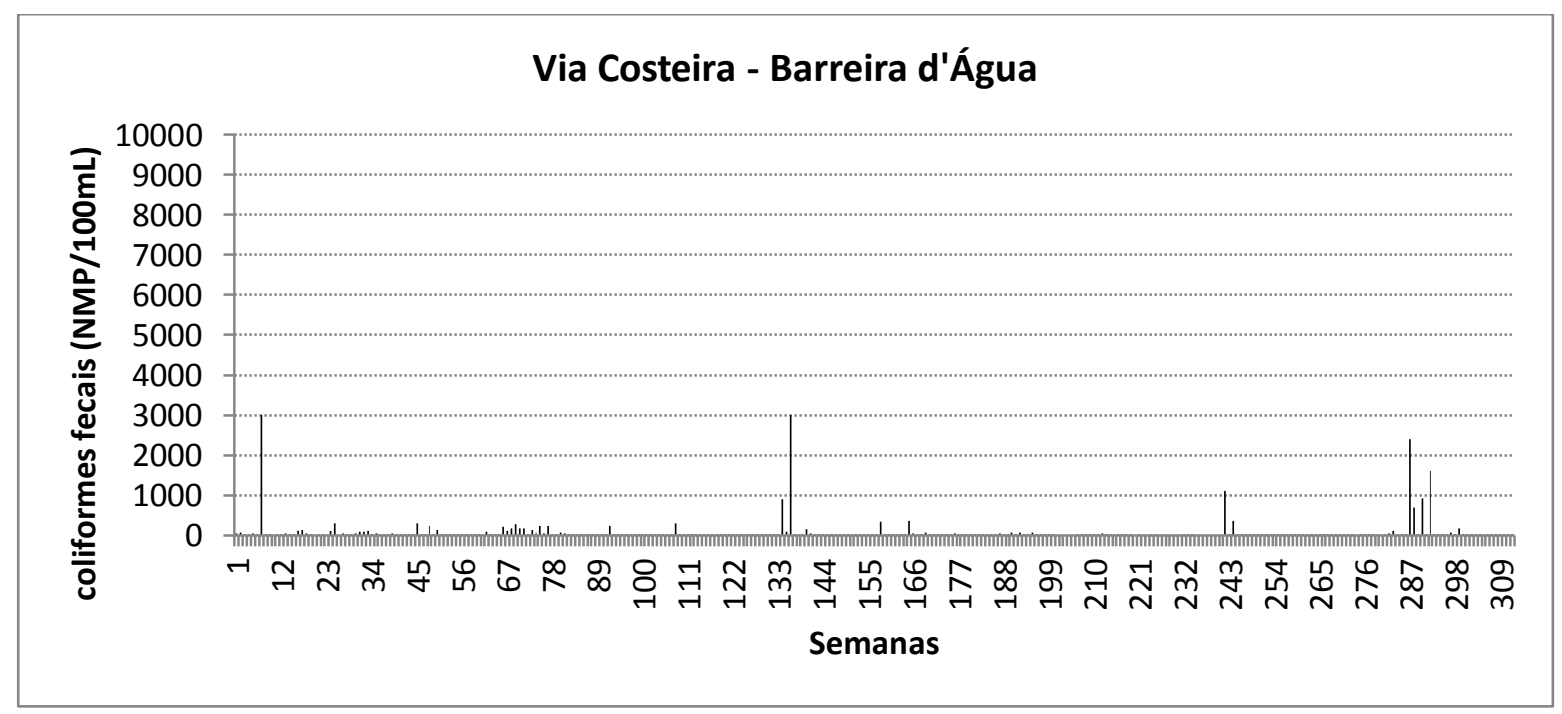

Figura 7 - Evolução temporal da quantidade de coliformes fecais encontrada na estação de monitoramento NA-06, no período de 2004 a 2009. Fonte: Dados da pesquisa.

Outra forma de avaliar a qualidade da balneabilidade das praias é acompanhar sua evolução temporal em termos dos percentuais anuais obtidos para a classificação PRÓPRIA para banho. Tal análise permite avaliar se houve uma melhoria ou não na sua qualidade, possibilitando a adoção de medidas preventivas em caso de perda de qualidade. Desta forma, também foram realizadas análises de evolução da qualidade ambiental com base nos percentuais anuais apresentados para cada uma das estações de monitoramento, cujos resultados são apresentados na Figura 9. Nota-se que a estação NA07 foi a que apresentou a pior qualidade ambiental ao longo da série. Nos anos de 2005 e 2007 a mesma se encontrou 100\% IMPRÓPRIA para banho ao longo de todo o ano. Sua melhor condição de balneabilidade foi em 2008 quando 
o percentual de PRÓPRIA para banho chegou a $64,7 \%$. As demais praias apresentaram um percentual anual alto de PRÓPRIA para banho, com valores superiores a 90\%, excetuando-se apenas a estação NA01 em 2009 com 88\%, e NA03 nos anos de 2005 e 2006 com 77\% e 86,5\%, respectivamente. Salienta-se ainda que a estação NA06 apresentou condições de balneabilidade PRÓPRIA para banho com valores acima de $96 \%$ para cada um dos anos. Através da análise ano a ano observa-se que a estação NA06 demonstrou um comportamento estável de boa qualidade ambiental ao longo dos anos, com oscilação de apenas $2 \%$ entre cada ano. As demais estações apresentaram uma queda de qualidade de 2004 para 2005 e uma ligeira queda de 2008 para 2009, onde NA01 e NA07 apresentaram as piores qualidades, com quedas de $8 \%$ e $14,7 \%$, respectivamente. De uma maneira geral, pode-se dizer que, exceto por NA07, todas as estações apresentaram pequenas oscilações ao longo do período, mantendo sua condição como PRÓPRIA para banho.

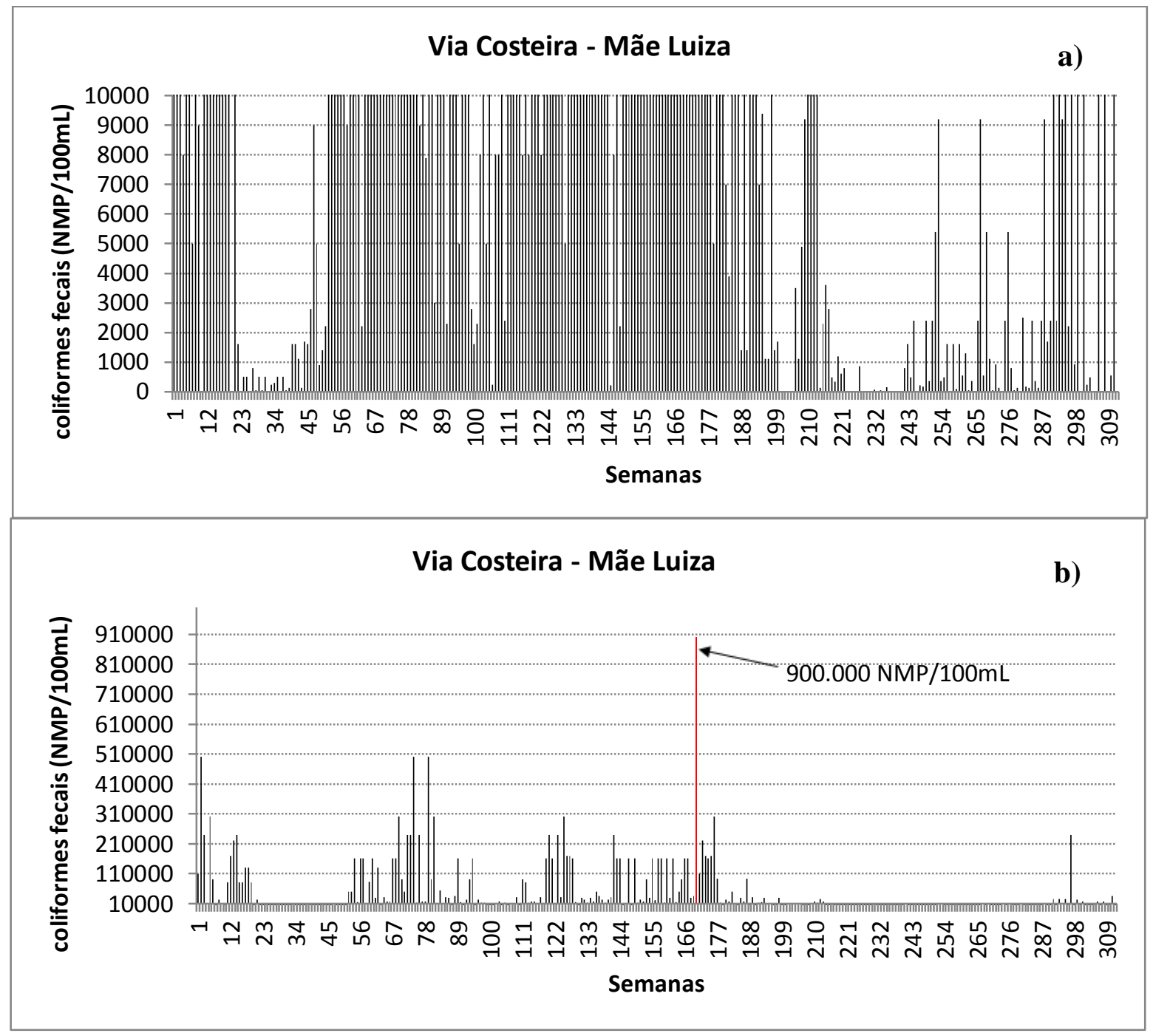

Figura 8 - Evolução temporal da quantidade de coliformes fecais encontrada na estação de monitoramento NA-07, no período de 2004 a 2009: a) eixo variando de 0 a $10.000 \mathrm{NMP} / 100 \mathrm{~m}$, e b) eixo variando de $10.000 \mathrm{NMP} / 100 \mathrm{~mL}$ a $910.000 \mathrm{NMP} / 100 \mathrm{~mL}$. Destaque em vermelho ao maior valor alcançado, ocorrido na semana 170 (abril/2007). Fonte: Dados da pesquisa. 


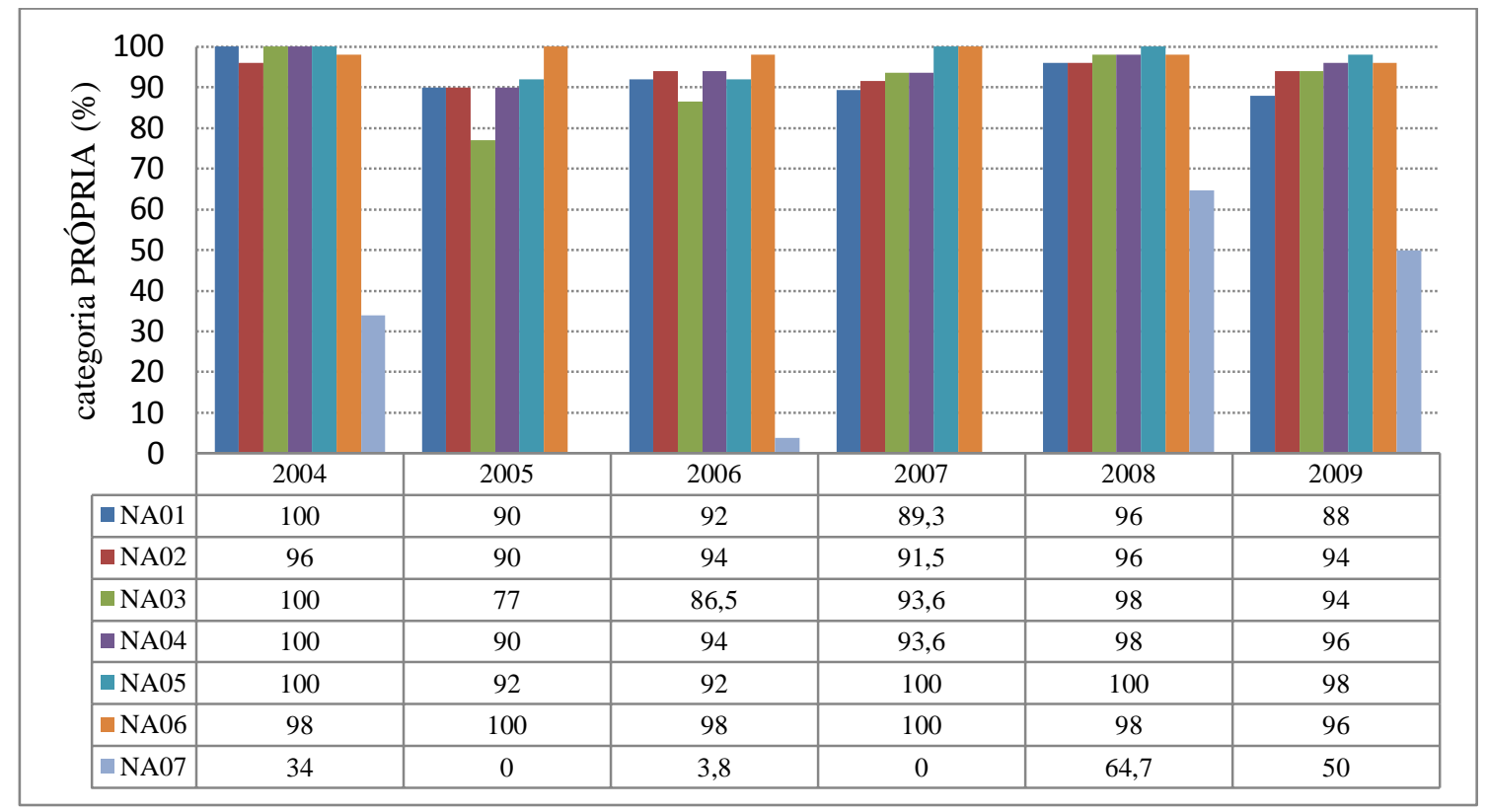

Figura 9 - Evolução percentual anual da condição de PRÓPRIA para banho das praias de Natal/RN. Fonte: Dados da pesquisa.

As condições de balneabilidade de uma praia podem sofrer influência de vários fatores, entre eles tem-se a precipitação, marés, correntes marinhas e ventos, esgotamento sanitário e sistema de drenagem, expansão urbana desordenada, etc. Sales (2006) em estudo realizado sobre a balneabilidade das praias de Natal durante o ano de 2005 sugeriu que o número mais provável de coliformes fecais apresentou-se elevado para aqueles dias em que houve alta incidência de chuvas coincidindo e/ou antecedendo as coletas de amostras. Sugestão semelhante foi feita por Nemetz (2004) ao realizar estudo sobre a balneabilidade de praias do litoral centronorte de Santa Catarina.

Assim, com base nessa premissa, foi realizada uma análise da distribuição de precipitação em Natal visando avaliar se houve influência desta na qualidade ambiental das praias durante o período estudado. Natal se caracteriza por apresentar uma estação chuvosa que tem início no mês de março e se estende até agosto, sendo que o principal período, também conhecido como quadra chuvosa, compreende os meses de abril-julho, conforme ilustra a Figura 10. Os totais mensais e anuais de precipitação registrados na cidade durante o período de 2004 a 2009 encontram-se na tabela 3. 


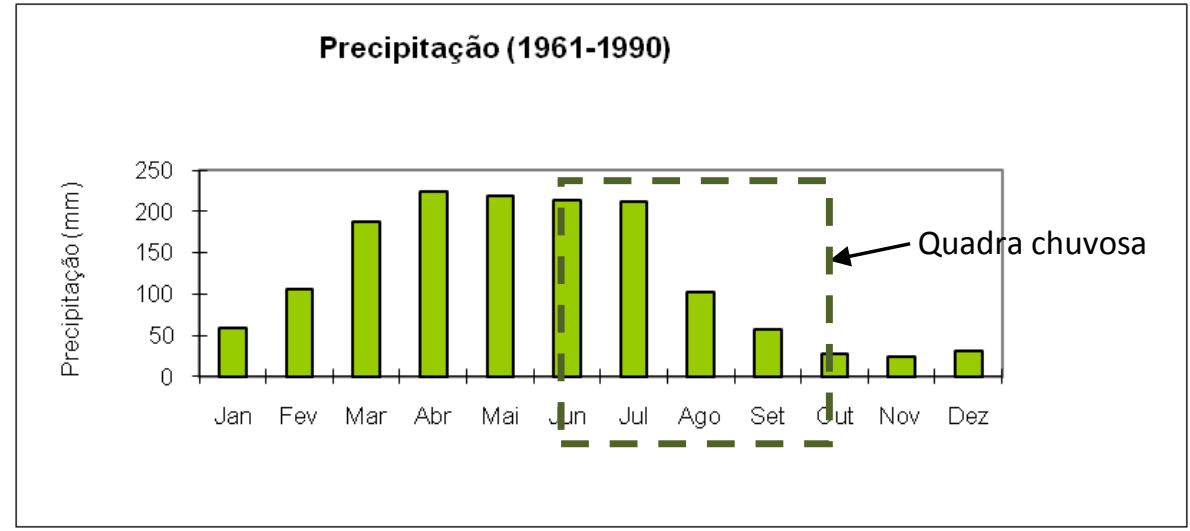

Figura 10 - Ciclo anual do total mensal de precipitação com base nas normais climatológicas de referência (1961-1990) para a região de Natal/RN. Fonte: Dados da pesquisa (dados primários fornecidos pela EMPARN).

Tabela 3- Totais mensais e anuais de precipitação $(\mathrm{mm})$ de Natal/RN do período de 2004 a 2009. O retângulo destaca a estação chuvosa e, em negrito, os anos mais chuvosos. Fonte: Dados da pesquisa (dados primários fornecidos pela EMPARN).

\begin{tabular}{|c|c|c|c|c|c|c|}
\hline & 2004 & 2005 & 2006 & 2007 & 2008 & 2009 \\
\hline Jan & 383,9 & 2,0 & 4,2 & 86,3 & 69,4 & 162,1 \\
\hline Fev & 283,0 & 36,4 & 87,2 & 65,9 & 22,4 & 245,7 \\
\hline Mar & 252,0 & 186,3 & 157,4 & 260,3 & 270,9 & 220,6 \\
\hline$A b r$ & 167,8 & 144,0 & 427,9 & 245,4 & 409,2 & 364,3 \\
\hline Mai & 160,7 & 548,2 & 115,3 & 120,9 & 212 & 372,3 \\
\hline Jun & 642,9 & 761,3 & 375,1 & 560,4 & 538 & 304,5 \\
\hline Jul & 393,4 & 126,9 & 133,3 & 191,8 & 473,1 & 347,9 \\
\hline Ago & 90,1 & 134,4 & 90,3 & 95,8 & 401,1 & 229,2 \\
\hline Set & 44,4 & 43,9 & 45,2 & 46,2 & 37,8 & 76,7 \\
\hline Out & 13,0 & 31,6 & 13,4 & 20,2 & 31,8 & 1 \\
\hline Nov & 10,1 & 1,2 & 83,5 & 45,2 & 9,5 & 6,7 \\
\hline Dez & 4,8 & 10,4 & 49,8 & 16,0 & 0,4 & 9,5 \\
\hline Total anual & 2446,1 & 2026,6 & 1582,6 & 1754,4 & 2475,6 & 2340,5 \\
\hline
\end{tabular}

Percebe-se que, em termos de totais anuais, o ano de 2008 foi o ano mais chuvoso da série seguido por 2004 e 2009. A fim de avaliar as relações entre a distribuição das chuvas e a balneabilidade, foi feita uma representação gráfica qualitativa da evolução semanal das condições de balneabilidade segundo as resoluções do CONAMA (Figura 11). Destaca-se que, apesar de os meses de janeiro e fevereiro de 2004 terem sido bastante chuvosos, apenas 3 estações apresentaram condições IMPRÓPRIAS para banho, sendo uma delas a NA07 (Mãe Luiza) que conforme se percebe apresentou condições IMPRÓPRIAS na maioria das semanas analisadas, independentemente da época do ano. Salienta-se ainda que, embora 2004 tenha tido precipitações significativas ao longo de período chuvoso, com exceção da NA07, nenhuma outra estação apresentou condições IMPRÓPRIAS. Embora o ano de 2008 tenha apresentado valores 
mensais superiores ao ano de 2004 na estação chuvosa, apenas 2 estações apresentaram condição IMPRÓPRIA para banho, ao passo que o número de praias IMPRÓPRIAS aumentou no mês de setembro quando a distribuição de precipitação já havia diminuído significativamente. Já o ano de 2005 apresentou uma concentração de praias em condições IMPRÓPRIAS exatamente no período chuvoso, cuja única exceção foi a estação NA06. A análise da evolução temporal da quantidade de coliformes fecais (ilustrada nas Figuras de 2 a 8) evidenciou que a maioria das estações apresentou índices de coliformes bastante elevados em 2005, principalmente nos meses de maio e junho os quais foram os mais chuvosos daquele ano.

Uma análise mais detalhada para o ano de 2005 foi realizada tomando como base a data da coleta das amostras e a precipitação diária registrada no período. Na Figura 12 encontra-se ilustrada a distribuição da quantidade de coliformes fecais para as estações NA01, NA02, NA03, NA05 e NA06 ao longo dos meses de maio e junho e na Figura 13 a distribuição semanal de precipitação acumulada no período correspondente ao dia da coleta das amostras para estes meses. Uma análise de ambas as figuras mostra que não existe uma relação direta entre a quantidade de coliformes fecais encontradas nas amostras e a quantidade de precipitação acumulada na semana. Observa-se, por exemplo, que a maior precipitação ocorreu na terceira semana com total de $258,5 \mathrm{~mm}$ acumulado nesta semana, entretanto, excetuando-se a estação NA07, todas as demais apresentaram valores de coliformes inferiores a $300 \mathrm{NMP} / 100 \mathrm{~mL}$, encontrando-se em situação EXCELENTE ou MUITO BOA. Situação semelhante ocorreu na última semana de julho, com total de precipitação de $193,7 \mathrm{~mm}$, porém as estações de NA01 a NA06 apresentaram valores de coliformes inferiores a $80 \mathrm{NMP} / 100 \mathrm{~mL}$, classificada como EXCELENTE. A estação NA07 apresenta um comportamento quase inverso ao da distribuição de precipitação e a estação NA04 apresentou a maior quantidade de coliformes fecais na semana 22, todavia a precipitação no período foi de $71,5 \mathrm{~mm}$. As análises realizadas para os demais anos (gráficos não mostrados) também evidenciam, de um modo geral, não ser possível estabelecer uma relação direta entre aumento da quantidade de coliformes fecais e precipitação, embora se perceba que as quantidades elevadas de coliformes coletados na semana 23/2005 sofreu influência da enorme quantidade de precipitação que ocorreu durante esta semana. Destaca-se que a quantidade de precipitação foi de $349,8 \mathrm{~mm}$, muito acima na média climatológica do mês de junho que é em torno de $220 \mathrm{~mm}$. 


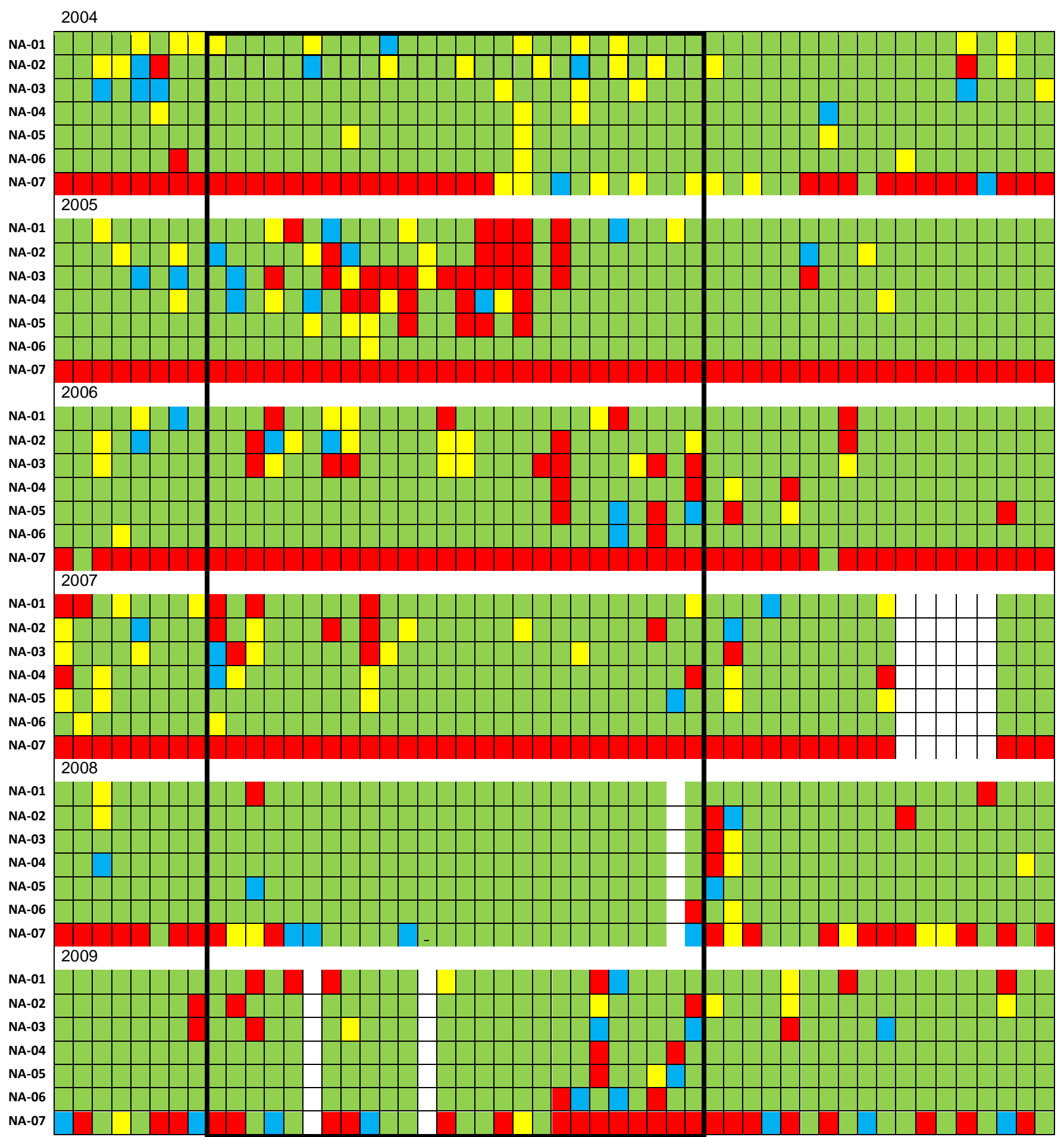

Figura 11 - Evolução semanal da balneabilidade das praias de Natal/RN ao longo do período de 2004 a 2009: verde corresponde à condição EXCELENTE, amarelo à MUITO BOA, azul à SATISFATÓRIA e vermelho para IMPRÓPRIA. A cor branca representa as semanas em que não houve coleta de amostras. $O$ período chuvoso (destacado no retângulo preto) vai de março a agosto, compreendendo as semanas de 9 a 34. Fonte: Dados da pesquisa. 


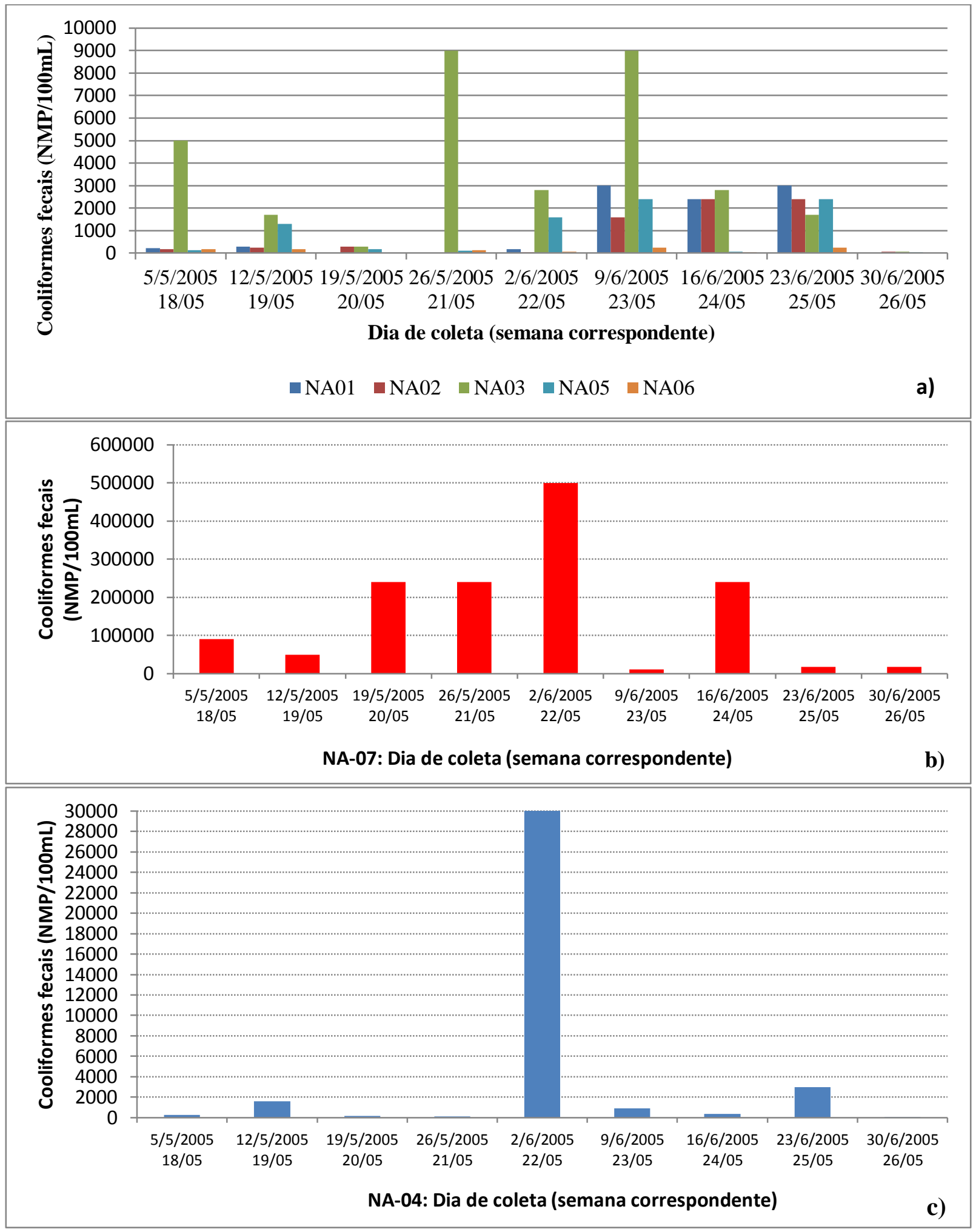

Figura 12 - Quantidade de coliformes fecais (NMP/100mL) encontradas ao longo dos meses de maio e junho de 2005: a) para as estações NA01, NA02, NA03, NA05 e NA06; b) para a estação NA07; e, c) para a estação NA04. Fonte: Dados da pesquisa. 


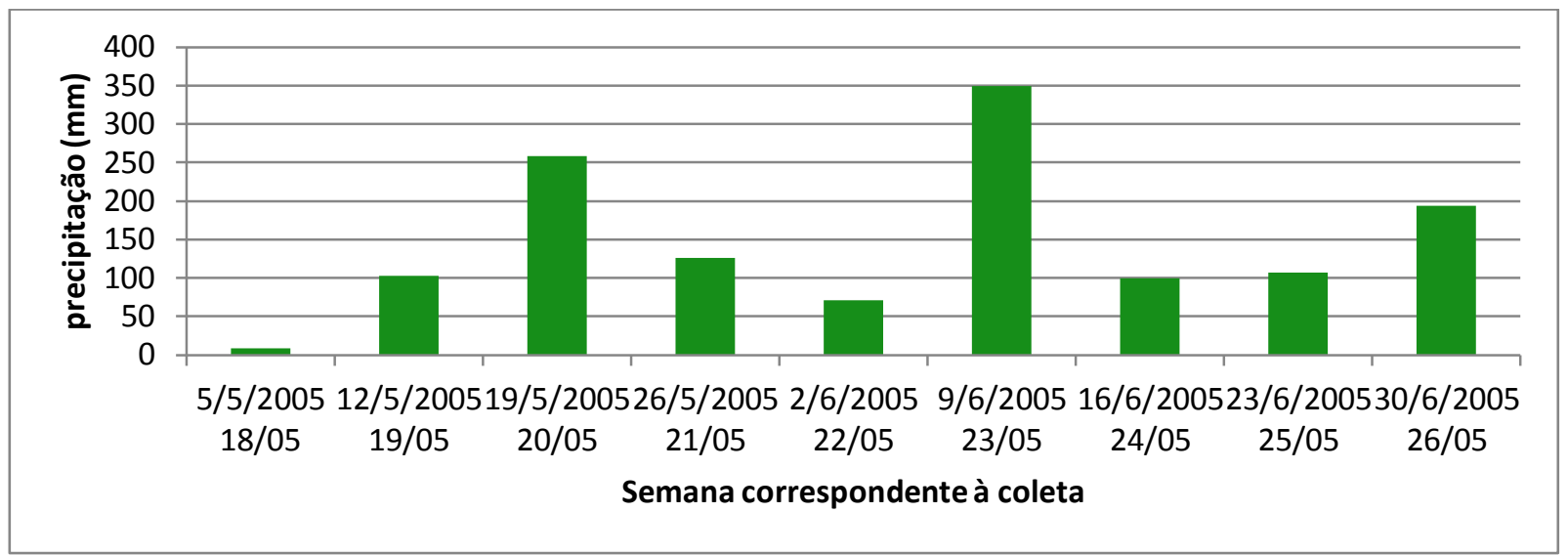

Figura 13 - Distribuição semanal de precipitação $(\mathrm{mm})$ em Natal acumulada no período correspondente à data de coleta das amostras, ao longo dos meses de maio e junho de 2005. Fonte: Dados da pesquisa.

\section{CONSIDERAÇÕES FINAIS}

O estudo da qualidade ambiental das praias de Natal constou do monitoramento de sete estações realizado pelo programa Água Azul durante cinquenta e duas semanas consecutivas, ao longo do período de 2004 a 2009. Os resultados indicaram que, de forma geral, as praias de Natal possuem boa qualidade ambiental, onde apenas a praia da Via Costeira/Mãe Luíza (NA07) apresentou continuamente elevados índices de contaminação, mantendo, portanto, as piores condições para banho. Relatórios emitidos pela programa Água Azul apontam como causa principal a deficiência ou inexistência de um sistema de coleta e tratamento de esgotos domésticos, com a conseqüente descarga destes na praia (IDEMA, 2005, 2008).

Já as praias da Via Costeira/Barreira d'Água (NA06) e da Via Costeira/Cacimba do Boi (NA05) destacaram-se como praias com as melhores condições ambientais, apresentando percentagens anuais de PRÓPRIA para banho superiores em $98 \%$ e $92 \%$, respectivamente. Sabese que a precipitação é um dos fatores que influencia a qualidade ambiental de uma praia, porém não foi possível estabelecer uma relação direta entre a quantidade de precipitação e de coliformes fecais para Natal para as estações avaliadas. Com base nos resultados apresentados percebe-se que apenas a distribuição da precipitação não foi capaz de explicar a grande variabilidade apresentada na qualidade ambiental das praias urbanas de Natal.

Inúmeros outros fatores podem estar influenciando a qualidade das praias, como movimento das marés, direção e velocidade dos ventos, correntes oceânicas, deságüe de galerias de águas pluviais contaminadas, bem como outras fontes de poluição de origem antrópica. A praia de Ponta Negra é uma das que possui vários pontos de deságüe de galerias pluviais, apresentando problemas constantes de extravasamento de esgoto doméstico proveniente de ligação clandestina. Todavia, uma análise mais detalhada envolvendo este e outros fatores foge ao escopo deste trabalho.

Por fim, considerando-se que a praia da Via Costeira/Mãe Luíza (NA07) já apresenta uma constante degradação ambiental, cujos prováveis focos de poluição estejam relacionados às ligações clandestinas dos esgotos domésticos, e cuja situação de má qualidade põe em risco a 
saúde da população, podendo resultar em prejuízos também financeiros (saúde pública e patrimônio turístico-econômico), recomenda-se aos órgãos ambientais competentes tomar ações corretivas e preventivas necessárias à manutenção da integridade sanitária do litoral de Natal.

\section{AGRADECIMENTOS}

Os autores agradecem ao programa Água Azul por ter gentilmente cedido os dados das estações de monitoramento das condições de balneabilidade e também à EMPARN pelos dados de precipitação.

\section{REFERÊNCIAS BIBLIOGRÁFICAS}

1. BARBIERI, José Carlos. Desenvolvimento sustentável regional e municipal: conceitos, problemas e pontos de partidas. 2000. Disponível em:

<http://www.fecap.br/adm online/art14/barbieri.htm>. Acesso em: 29 set. 2009.

2. CLARK, John R. Coastal zone management - handbook. Flórida:CRC Press, 1996.

3. CONAMA. Resolução CONAMA № 20, de 18 de junho de 1986. Brasília-DF (Brasil), Conselho Nacional de Meio Ambiente, Ministério do Meio Ambiente, 1986.

4. CONAMA. Resolução CONAMA № 274, de 29 de novembro de 2000. Brasília-DF (Brasil), Conselho Nacional de Meio Ambiente, Ministério do Meio Ambiente, 2000.

5. IDEMA. Comportamento da balneabilidade das praias potiguares durante o ano de 2004: relatório síntese. Natal-RN, 26p., 2005.

6. IDEMA. Tomo II - Monitoramento das condições de balneabilidade das praias do Rio Grande do Norte no período de agosto a novembro de 2008. Natal-RN, 20p., 2008.

7. IFRN. Projeto estudo de balneabilidade das praias do estado do Rio Grande do Norte. 2010. Disponível em:< http://www.programaaguaazul.com.br/programa.php $>$. Acesso em: abr. 2010.

8. MATTOS, Katty Maria da Costa, FERRETTI FILHO, Neuclair João e MATTOS, Arthur. Uma abordagem conceitual sobre a valoração econômica de recursos naturais. 2000. Disponível em: <http://www.cpap.embrapa.br/agencia/congresso/Socio/MATTOS-043.pdf $>$. Acesso em: 28 set. 2009.

9. NEMETZ, Stella Maris Martins Cruz Castelo de Souza. Balneabilidade de praias do litoral centro-norte de Santa Catarina: estudo de percepção ambiental. Dissertação (mestrado em Eng. Ambiental), FURB, Blumenau-SC, 223p., 2004.

10. PORTILHO, Fátima. Consumo "verde", democracia ecológica e cidadania: possibilidades de diálogo? 2009. Disponível em:< http://www.rubedo.psc.br/Artigos/consumo.htm>. Acesso em: 29 set. 2009.

11. PORTILHO, Fátima. Consumo sustentável: limites e possibilidades de ambientalização e politização das práticas de consumo. 2005. Disponível em: < www.ebape.fgv.br/cadernosebape>. Acesso em: 29 set. 2009. 
12. SACHS, Ignacy. A terceira grande transição: da era petrolífera para a biocivilização. 2008. Disponível em: <http://www.edco2.com.br/ingles/artigos 02.php?id=20>. Acesso em: 23 set. 2009.

13. SALES, Thaise Emmanuele Andrade de. Estudo da balneabilidade das praias urbanas do município de Natal-RN durante o ano de 2005. Dissertação (mestrado em Eng. Sanitária), UFRN, Natal-RN, 108p., 2006.

14. SEILERT Villi. O valor econômico das coisas da natureza e o valor jurídico do meio ambiente. 2009. Disponível em: <http://www.artigonal.com/print/950780.2009>. Acesso em: 22 out. 2009. 